\title{
Do apreço liberal pela contenção do soberano ao caos prisional: reações de atores coletivos da direita liberal perante eventos no sistema carcerário de janeiro de 2017.
}

\author{
Otávio Dias de Souza Ferreira ${ }^{1}$
}

\begin{abstract}
Resumo
O trabalho investiga como atores coletivos da sociedade civil situados à direita no espectro político-ideológico e autoidentificados com valores do liberalismo manifestaram-se a respeito de episódios trágicos ocorridos em estabelecimentos prisionais em vários estados do Brasil em janeiro de 2017, período marcado por reiteradas notícias de rebeliões, fugas e mortes em estabelecimentos prisionais, assunto que ganhou destaque nas redes sociais com manifestações das mais diversas tonalidades no espectro político ideológico. Parte-se da premissa segundo a qual os direitos civis de defesa do súdito contra abusos do soberano constituíram-se numa edificação das raízes do liberalismo político. Embora a maioria dos resultados seja no sentido de silêncio e omissão, constatam-se manifestações distribuídas entre um polo de apreço liberal pela contenção do soberano e outro que denotaria alguma propensão autoritária dos atores. Destaca-se que os atores com institucionalidade mais forte e com âmbito de atuação mais voltado para a formação de pessoas e difusão de valores liberais mostraram mais apreço pelo princípio de restrição de poder do soberano do que os menos institucionalizados e mais voltados para a ação política direta.

Palavras-chave: direitos humanos; liberalismo; prisões; direitos civis; direita política; sociedade civil.
\end{abstract}

\begin{abstract}
From the liberal esteem for the sovereign's restraint to the chaos in prisons: reactions of liberal right-wing collective actors towards the January 2017's events within the prison system.

The present work investigates the reactions of collective actors of the civil society situated to the right side of the political-ideological spectrum and self-identified with liberal values regarding tragic episodes occurred inside prisons in several states of Brazil in January 2017, a period marked by reiterated rebellions, escapes and deaths which took place in prisons, a subject that has gained prominence in social networks with manifestations of a wide range of tonalities in the political-ideological spectrum. It starts from the premise that the subject's civil rights of defense against sovereign's abuses are in the roots of political liberalism. Although most of the results
\end{abstract}

\footnotetext{
${ }^{1}$ Otávio Dias de Souza Ferreira é doutorando em Ciência Política pela Universidade de São Paulo, membro do Núcleo Direito e Democracia do CEBRAP. "O presente trabalho foi realizado com apoio da Coordenação de Aperfeiçoamento de Pessoal de Nível Superior - Brasil (CAPES) - Código de Financiamento 001"
} 
verified are in the sense of silence and omission, we found manifestations varying from liberal appreciation for sovereign's restraint to authoritarian propensity of some actors. The actors with a stronger institutional structure and more dedicated to the formation of people and the diffusion of liberal values showed more esteem for the principle of sovereign's restraint than the less institutionalized actors and more directed toward direct political action.

Key-words: human rights; liberalism; prisons; civil rights; right wing; civil society.

\section{Introdução}

$\mathrm{Na}$ crescente polarização constatada no cenário político brasileiro, agravada depois das eleições gerais de 2014, o debate público dividiu com alguma animosidade amplos setores da população. Sobretudo a partir de 2015 , enquanto conservadores e liberais do campo da direita política juntaram suas forças na defesa da deposição da Presidente da República Dilma Rousseff, vertentes da esquerda uniram-se na defesa da continuidade do mandato. Depois de um período de muita tensão em um processo de impeachment, o resultado foi sacramentado pelo Congresso Nacional e legitimado formalmente pelo Supremo Tribunal Federal ${ }^{2}$. Se parte da oposição ao governo do Partido dos Trabalhadores nunca aceitara o resultado eleitoral de 2014, o lado derrotado pelo impeachment não admitiu a legitimidade do processo, considerando-o uma espécie de golpe de estado, e nem tampouco das reformas e políticas públicas implementadas pelo sucessor na chefia do Executivo. A discórdia permaneceu e a crise social, política e econômica apenas se aprofundou nesses últimos tempos.

No âmbito dessas disputas tem merecido algum destaque de estudiosos das ciências sociais, como fenômeno social novo, o protagonismo no debate público atingido por atores coletivos da direita política ${ }^{3}$. Sabe-se que muitos desses atores não são propriamente novos, mas alguns dos mais antigos passaram por processos de

\footnotetext{
${ }^{2}$ Essa história e muitos dos conflitos são descritos e analisados de modo pormenorizado por Singer (2018).

${ }^{3}$ Nesse sentido, podemos citar a elaboração da obra organizada por Velasco e Cruz, Kaysel e Codas (2015), a organização de Seminários como o "Conservadorismo e nova direita: idéias e movimentos", na Unicamp em 2015, o Seminário "Conservadorismos, Novas Direitas e Grupos insurgentes, na PUC-SP em 2018, e o 1옷 Simpósio Direitas Brasileiras, na Universidade de São Paulo em 2017, a publicação do dossiê temático na revista Cult (2018) entre outras reportagens, análises e entrevistas com estudiosos, publicadas em periódicos diversos, buscando compreender melhor esse fenômeno.
} 
transformação e repaginação, visando conquistar outros públicos para além dos seus tradicionais (Rocha, 2015).

Entre as crenças em disputa nas mais diversas áreas políticas, vamos nos interessar aqui mais especificamente pela investigação de manifestações concernentes ao sistema punitivo e aos direitos civis de uma pluralidade de atores coletivos autoidentificados com o campo liberal cujos posicionamentos permitam posicioná-los à direita no espectro político-ideológico. Mais especificamente, o objeto da pesquisa empírica refere-se ao posicionamento de diversos grupos com relação aos acontecimentos trágicos ocorridos em estabelecimentos prisionais de todo o país em janeiro de 2017.

A compreensão do cenário complexo e da heterogeneidade de pensamentos políticos em disputa nesse "ecossistema" (Rocha, 2018) em construção é algo que demanda esforços empíricos no sentido de apurar, sistematizar e classificar determinadas afinidades e distinções entre as crenças dos atores em diversas áreas do mundo social. O presente trabalho tem o intuito de colaborar com tal agenda de pesquisa a partir da realização de um exercício empírico de observação de publicações de dezoito desses atores em uma rede social, com base em determinadas concepções liberais de limitação do poder soberano que inspiraram os esforços revolucionários do século XIX.

O artigo é dividido em quatro seções, além desta introdução e das considerações finais. Na primeira, narramos brevemente os acontecimentos ocorridos no sistema prisional em janeiro de 2017 , de modo a dimensionar a importância e o potencial de repercussão na esfera pública daqueles fatos. Em seguida, fazemos uma breve discussão teórica sobre a direita e a tradição liberal no Brasil. A terceira parte trata dos critérios de escolha dos atores, de categorias adotadas e de algumas dificuldades e limitações para a realização da pesquisa empírica. A última parte apresenta os resultados empíricos onde, apesar da maioria dos atores terem silenciado sobre os fenômenos prisionais, entre aqueles que se manifestaram, evidencia-se uma diferença qualitativa ligada entre aqueles atores que denotam mais apreço por esse princípio liberal da restrição de poder do soberano e aqueles cujas manifestações apontam para uma propensão autoritária. As primeiras têm um processo mais 
consolidado de institucionalidade e uma vocação institucional distinta em relação às últimas.

\section{Os episódios no sistema penitenciário de janeiro de 2017}

Rebeliões e tentativas de fuga no sistema penitenciário brasileiro não são raras na história recente. Considerando apenas casos recentes, desde setembro até dezembro de 2016, cerca de 550 presos fugiram das unidades prisionais do estado de São Paulo (Folha de São Paulo, 2017b). Mas o início de janeiro de 2017 concentrou um excesso de eventos trágicos e de desordem no sistema prisional, com repercussão em quatro das cinco regiões do país ${ }^{4}$. Com destaque para eventos em Amazonas, Roraima, Rio Grande do Norte e no interior de São Paulo, várias rebeliões com tentativas de fuga eclodiram em numerosos estabelecimentos em diversos estados da federação.

Tudo começou logo na virada do ano quando, em 01 e 02 de janeiro de 2017, uma série de rebeliões atingiu o complexo penitenciário Anísio Jobim, o centro de detenção provisória masculino, a unidade prisional de Puraquequara e o instituto penal Antonio Trindade, todos em Manaus, no Amazonas. No total foram contabilizadas sessenta mortes e cento e oitenta fugas. Como desdobramento desses fatos, nos dias que se seguiram, registraram-se doze homicídios no município de Manaus, em uma “onda de violência" desencadeada após a rebelião ${ }^{5}$. Em 08 de janeiro de 2017 uma rebelião na cadeia pública Raimundo Vital Pessoa, em Manaus, culminou com mais quatro mortes ${ }^{6}$.

No dia 06 de janeiro de 2017 uma grande rebelião ocorreu em Roraima, na penitenciária agrícola Monte Cristo, em Boa Vista, tendo como resultado a morte de trinta e três internos ${ }^{7}$. No dia dez, mais de cem agentes da Força Nacional de Segurança

\footnotetext{
${ }^{4}$ Apenas a região Centro-Oeste não registrou algum episódio crítico no sistema carcerário em janeiro de 2017.

${ }^{5}$ Ver reportagem “Manaus registra 12 homicídios após rebelião e fugas de presos”, do G1 (2017b).

${ }^{6}$ Ver reportagem "Manaus registra novas mortes de presos e rebeliões; veja histórico", de A Tribuna (2017).

${ }^{7}$ Ver reportagem "Veja quem são todos os 31 dos 33 mortos no massacre de Roraima”, de Folha de São Paulo (2017d)
} 
foram enviados para reforçar a segurança pública nos arredores do presídio. No dia 12, nove tentativas de fuga ocorreram ${ }^{8}$.

No dia 12 de janeiro de 2017 na penitenciária de Tupi, no interior de São Paulo, dois morreram depois de uma suposta briga entre os detentos ${ }^{9}$.

Em 14 de janeiro de 2017 foi a vez da Bahia. No complexo penitenciário de Mata Escura, em Salvador, são contabilizadas trinta e oito fugas e na 4a Coordenadoria da Polícia Civil de Santo Antonio de Jesus, outras vinte e uma ${ }^{10}$.

No dia 15 de janeiro de 2017 começou uma série de conflitos a partir de uma grande rebelião na penitenciária de Alcaçus, na região metropolitana de Natal, Rio Grande do Norte. Nos primeiros dois dias a estimativa de mortes era de vinte e seis detentos. A polícia invadiu o complexo e não conseguiu dominar a situação de imediato. Presos seguiram amotinados em uma parte do complexo e a cada dia a expectativa era de mais mortos e feridos ${ }^{11}$.

Na mesma data, no complexo de Piraquara, em Curitiba, no Paraná, uma explosão nos muros do estabelecimento permitiu a evasão de vinte e oito detentos. Dois internos foram mortos no episódio ${ }^{12}$.

Também no dia 15 de janeiro de 2017, na unidade prisional de Ibirité, na Zona Metropolitana de Belo Horizonte, em Minas Gerais, dez fugas foram contabilizadas ${ }^{13}$.

Em 18 de janeiro de 2017 na penitenciária estadual do Seridó, em Caicó, no Rio Grande do Norte, eclodiu uma rebelião com pelo menos um morto e incidentes foram registrados para além dos muros ${ }^{14}$.

No dia seguinte um preso foi encontrado morto em cela do complexo penitenciário de Gericinó, em Bangu, no Rio de Janeiro. Tratava-se da décima sétima

\footnotetext{
${ }^{8}$ Ver reportagem "Presos tentam fugir de penitenciária alvo de massacre em Roraima ", do Uol (2017e).

9 Ver reportagem "SP registra as primeiras mortes em presídios no ano, no Brasil são 103", do Uol (2017f).

${ }^{10}$ Ver reportagem "Em menos de 24 horas, 38 detentos fogem de presídios na Bahia” , do Uol (2017c).

${ }^{11}$ Ver reportagem "Cadeia está virada, diz diretor de Alcaçus; presos estão nos telhados”, da Folha de São Paulo (2017a).

${ }^{12}$ Ver reportagem "Após explosão de muro, presos fogem de penitenciária do Paraná", do G1 (2017a).

${ }^{13}$ Ver reportagem "Dez detentos fogem de presídio na região metropolitana de BH", do Uol (2017a).

${ }^{14}$ Ver reportagem "RN registra rebelião em mais uma unidade prisional", do G1 (2017d)
} 
morte de presos no ano naquele estado da federação, praticamente uma para cada dia daquele mês de janeiro ${ }^{15}$.

Finalmente, em 23 de janeiro de 2017, no Centro de Progressão 3 de Bauru, no interior de São Paulo, uma grande rebelião resultou em cerca de cento e cinquenta e duas fugas ${ }^{16}$.

No total, estima-se que houve um número superior de mortos em janeiro de 2017 do que no famoso episódio da capital paulista de 02 de outubro de 1992, conhecido popularmente como o "Massacre do Carandiru". Um relatório divulgado em maio daquele ano pelo Mecanismo Nacional de Prevenção e Combate à Tortura, órgão da União ligado ao Ministério dos Direitos Humanos, concluiu pelo desaparecimento de setenta e um presos, sugerindo que o número de pessoas assassinadas, apenas no complexo de Alcaçus, próximo de uma centena ${ }^{17}$.

Alguns analistas na imprensa apressaram-se em batizar esse conjunto de episódios como "crise penitenciária"18. A expressão "crise" costuma se referir a eventos significativos de ordem mais esporádica e súbita ou a uma "fase difícil, grave, na evolução das coisas, dos fatos, das ideias" ou a "uma manifestação violenta e repentina de ruptura de equilíbrio" (Ferreira, 2004). É certo que cada estado da federação tem uma realidade peculiar de conflitos no sistema prisional. Aonde as condições forem mais degradantes e aonde ocorram disputas mais intensas entre grupos criminosos pela hegemonia do tráfico de drogas e do controle da gestão interna de unidades prisionais, é provável que sejam registrados mais fenômenos de rebeliões e de violência ${ }^{19}$. Sabese, por exemplo, que em São Paulo o processo de disputa por hegemonia na década de 1990 aumentou no primeiro momento as quantidades de fugas, resgates, rebeliões e

\footnotetext{
${ }^{15}$ Ver reportagem "Em 19 dias, 17 detentos morreram em unidades prisionais do Rio de Janeiro", do Uol (2017b).

${ }^{16}$ Ver reportagem "Mais de 6 horas após rebelião em Bauru (SP), governo diz que 152 presos fugiram”, do Uol (2017d).

${ }^{17}$ Ver reportagem "Para especialistas, caos no sistema penitenciário é regra em todo o país", do G1 (2017c).

18 Ver reportagens "Entenda a crise no sistema prisional brasileiro" da EBC (2017) e "Veja um resumo da crise nos presídios que deixou 102 mortos neste ano", da Folha de São Paulo (2017e).

${ }^{19}$ Não é o objetivo deste trabalho a busca por causas desses fenômenos, mas vale mencionar que alguns especialistas na questão prisional se manifestaram na época, como Arthur Trindade, Camila Nunes Dias, em reportagem da Folha de São Paulo (2017c) e João Marcos Buch, Maria Laura Canineu e João Pedro Paulo Bichalho, em matéria publicada na página do Conselho Regional de Psicologia do Mato Grosso do Sul (2017).
} 
mortes no sistema prisional, até que o período imediatamente posterior, de consolidação da liderança do Primeiro Comando da Capital no "mundo do crime", dentro e fora das prisões, resultou em uma redução significativa desses números (Dias, 2013). Janeiro de 2017 foi sim um período de intensificação desses eventos no país, mas talvez seja parte de um fenômeno mais contínuo e usual do que propriamente uma "crise".

Manifestações das mais diversas tonalidades no espectro político ideológico surgiram na rede mundial de computadores sobre os eventos desse período. Veremos adiante, de modo mais específico, como atores coletivos situados no campo da direita liberal brasileira se posicionaram em suas páginas da rede social "Facebook". Houve quem comemorasse as mortes e a violência perpetrada entre os presos, quem se revoltasse contra o alardeado dever do Estado de pagar indenizações às famílias das pessoas mortas e não foram poucos a insuflar as pautas pelo endurecimento da legislação penal. Mas antes de apresentarmos mais detalhadamente os resultados, é necessário transitarmos pelas premissas teóricas e metodológicas da pesquisa.

\section{Apontamentos teóricos}

Sob o rótulo de Liberais, podem ser assumidas doutrinas variadas e posições heterogêneas e, por vezes, conflitantes na leitura dos fatos políticos. É notório que a teoria liberal é muito ampla, comportando influências filosóficas distintas, desenvolvidas ao longo dos últimos séculos ${ }^{20}$, da esquerda à direita no espectro político-ideológico. Constituindo-se "uma família muito extensa" e eclética de princípios e doutrinas, o Liberalismo surgiu e se desenvolveu a partir de uma série de obras formuladas sem uma classificação consciente por parte de seus autores, do ponto de vista das classificações modernas, e sem um isolamento em relação às outras teorias políticas e aos debates políticos de seu tempo (Waldron, 2012).

Em verbete da Enciclopédia Stanford, Gaus, Courland e Schmidtz (2015) apresentam o "Liberalismo" como uma grande teoria política que vem sendo associada

\footnotetext{
${ }^{20}$ Para ter uma noção panorâmica das vertentes do Liberalismo, recomenda-se a leitura de Gauss (2015).
} 
com teorias amplas de ética, valor e sociedade, de modo a constituir um grande continuum de formulações teóricas construídas ao longo de séculos.

Segundo Amadeo (2015), a compreensão mais precisa sobre as origens do Liberalismo requer o estudo de amplos debates do pensamento político da Grã Bretanha em dois períodos críticos entre os séculos XVII e XVIII (1640-1660 e 16801720), para além da tradição que se concentra na leitura de Thomas Hobbes e John Locke. Passam por disputas significativas envolvendo a regulação e a distribuição da propriedade e sobre controvérsias operadas nas noções de liberdade e autoridade.

Importa aqui principalmente uma linha de pensamento político de cunho liberal surgida desde o final do século XVII e que vai influenciar fortemente os eventos revolucionários dos séculos seguintes, em defesa de direitos civis e questionador da legitimidade de certas ações das autoridades estatais e contra eventuais arbitrariedades cometidas pelos soberanos contra os súditos.

O princípio de resistência à repressão e tirania, de John Locke, por exemplo, pode ser articulado contra condutas de "exercício do poder para além do direito" (Mello, 2004, p. 87), por parte de agentes do Estado no sistema prisional. Merece destaque a defesa dos direitos do homem por parte de Thomas Paine (2005), preconizando a instauração de um governo da razão, baseado no interesse comum, a fim de superar as formas de governo anteriores, seja a fundada na superstição, seja a fundada na força.

Referimo-nos aos autores que Baratta (2002) vai enquadrar no que chama de “Escolas Liberais Clássicas"21 do direito penal ${ }^{22}$, ou seja, aqueles que se insurgiram contra as práticas penais e penitenciárias dos regimes de então, propondo princípios para uma nova ordem punitiva como os da legalidade e da humanidade. É nesse sentido que um pensador como Cesare Beccaria propõe, em 1764, um sistema de graduação de penas que considere a proporcionalidade entre a punição e o ato

\footnotetext{
${ }^{21}$ Como autores representativos desse movimento, Baratta (2002) destaca Jeremy Bentham, na Grã Bretanha, Alselm von Feuerbach, na Alemanha, e Cesare Beccaria, na Itália.

${ }^{22}$ Vale mencionar que o uso desse nome "Liberalismo Clássico" pode causar controvérsias na literatura dedicada ao pensamento político. No estudo de Gaus (s. d.), por exemplo, refere-se a uma tradição teórica do Liberalismo Econômico muito diversa dessa à qual Baratta (2002) se refere .
} 
cometido. A construção baseia-se em um princípio contratualista e de defesa da sociedade contra um desvio que feriu o pacto:

O interesse geral não se funda apenas em que sejam praticados poucos crimes, porém ainda que os crimes mais prejudiciais à sociedade sejam os menos comuns. Os meios de que se utiliza a legislação para obstar os crimes devem, portanto, ser mais fortes à proporção que o crime é mais contrário ao bem público e pode tornar-se mais frequente. Deve, portanto, haver proporção entre os crimes e os castigos (Beccaria, 1993. p. 61).

São autores que preconizam a instauração de uma racionalidade ao aparato punitivo. O Estado julgador passa a ser balizado por limites estabelecidos em leis escritas, que devem se impor sobre eventuais sentimentos individuais de vingança do soberano.

Liga-se, em um continuum histórico, à parte do pensamento liberal que Matteucci (2000) vai situar na "idade burguesa", mais especificamente no nível jurídico:

(...) a história do Liberalismo passaria pela história do Estado absolutista, uma vez que a afirmação do momento da autoridade seria a premissa necessária para uma liberdade autêntica, que não fosse apenas um privilégio de determinada classe ou grupo. O Liberalismo (e/ou democracia) representaria, desta forma, a reconquista pelas bases deste tipo de Estado, que já alcançou sua plenitude: o Liberalismo levaria à autolimitação do Estado para garantir os direitos públicos e subjetivos dos cidadãos; ao mesmo tempo, a democracia serviria para legitimar este Estado perante o sufrágio universal. (...) Do ponto de vista jurídico, o Liberalismo, por estar intimamente ligado ao constitucionalismo, sempre se manteve fiel ao princípio (medieval) da limitação do poder político mediante o direito, de tal forma que somente as leis são soberanas, justamente aquelas leis limitadora do poder do governo (Matteucci, 2000. p. 698).

É coerente com o pensamento desses liberais que a pena estabelecida em sentença, segundo os ditames legais, deva ser cumprida integralmente, sem excessos. Sendo ela a privação de liberdade por um certo período, é dever do Estado zelar pela vida e pela saúde da pessoa nesse interregno temporal.

Seguindo essa tradição de pensamento, vamos nos preocupar basicamente com manifestações referentes aos direitos civis de pessoas presas. Direitos sociais, econômicos e culturais, advindos de outras construções históricas, fogem do escopo de observação aqui, embora eventuais postagens nesse sentido possam ser mencionadas para contextualizar melhor a posição adotada pelo ator. 
Importante ressaltar que essa visão que enfatiza a defesa de direitos civis contra abusos do Estado contra os súditos não é restrita a um posicionamento no espectro político ideológico e é compartilhada por amplos setores da população, da direita à esquerda.

Em oposição aos princípios referidos dessa tradição do Liberalismo político, podemos vislumbrar uma perspectiva autoritária, que presume a legitimidade e a necessidade do uso da força por autoridades estatais, dispensando formas de controle de poder. O conceito mais amplo de Heywood (2002) de "autoritarianismo" pode ajudar a compreender onde se situa esse pensamento:

Authoritarianism is a belief in, or practice of, government 'from above', in which authority is exercised regardless of popular consent. Authoritarianism thus differs from authority. The latter rests on legitimacy, and that sense it arises "from below". Authoritarian regimes therefore emphasize the claims of individual liberty. However, authoritarianism is usually distinguished from totalitarianism. The practice of government 'from above' associated with monarchical absolutism, traditional dictatorships, and most forms of military rule is concerned with the repression to opposition and political liberty, rather than with the more radical goal of obliterating the distinction between the state and civil society. Authoritarian regimes may thus tolerate a significant range of economic, religious and other freedoms (Heywood, 2002. p. 38).

Essa ideia de governo de cima para baixo parece coerente com uma visão que dispensa controles democráticos sobre as autoridades do poder punitivo estatal, bem como a inversão da presunção de inocência dos suspeitos e acusados pela prática de infrações penais. De modo mais pragmático, e pensando em uma espécie de "senso comum" de setores da população brasileira, sobretudo posicionados à direita no espectro político-ideológico, essa visão parece coerente com a defesa de máximas como "bandido bom é bandido morto" ou "direitos humanos para humanos direitos" 23.

No Brasil há uma pluralidade de atores no espectro político-ideológico da direita. Kaysel (2015) esforça-se em busca de uma genealogia das direitas no país. Embora identifique muitas vertentes de pensamento e diferentes alinhamentos conforme o momento político, destaca que a literatura sobre o pensamento político aponta para certas continuidades em “longas 'tradições' ou 'linhagens' de pensamento

\footnotetext{
${ }^{23}$ Sobre esse fenômeno, o trabalho de Caldeira (2000) mostra como essas máximas tem ocupado o debate público brasileiro desde pelo menos o início dos anos 1980.
} 
que vamos muito sucintamente expor aqui. A reconstituição histórica começa da Independência brasileira em relação a Portugal, resultado de pactos entre as elites portuguesa e brasileira, quando se evitou conflitos tais como ocorridos na América espanhola. Garantiu-se a permanência da monarquia e da ordem escravocrata e não houve grandes rupturas no establishment. Dessa forma, a formação ideológica inicial seria de característica liberal-conservadora ${ }^{24}$. Essa realidade contribuiu para a fraca sedimentação do ideário dos liberais revolucionários. Tivemos uma primeira república mais caracterizada pela primazia liberal, ao passo que no período das décadas de 1920 e 1930 houve uma adesão crescente na direita em torno de correntes anti-liberais, com a defesa "de um Estado centralizador e da disciplina corporativista dos conflitos sociais" (p. 54). O período que se seguiu imediatamente depois da 2a Guerra Mundial, nossa "primeira experiência democrática propriamente dita", foi marcado pela crescente unificação da direita na oposição ao Varguismo e a uma aspiração de reformas em benefício sobretudo dos trabalhadores urbanos que alcançaria o seu momento mais forte no governo de João Goulart. Os liberais enfrentariam fortes resistências no campo da própria direita no recente regime militar, com a prevalência de um projeto nacional desenvolvimentista e com a restrição de liberdades civis. Nas últimas décadas, tornouse hegemônica na direita a defesa de políticas de liberalização econômica, que encontrou resistência nos governos do Partido dos Trabalhadores, quando a direita recomeçou um processo de unificação em torno de um inimigo comum.

O trabalho de Cruz (2015) tem interesse para a presente pesquisa ao inclinar-se para a compreensão da natureza da díade direita-esquerda aplicada ao contexto brasileiro. Valoriza a construção histórica desses conceitos e a especificidade de nossa realidade. Sua leitura coloca em relevo as influências externas ao longo da história no Brasil e em vizinhos da América Latina. O fascínio exercido pela "Civilização Europeia" e, mais recentemente, pelos Estados Unidos, em nossas elites, por vezes pode ter se combinado com o mecanismo do colonizador, observado por Gunnar Myrdal ${ }^{25}$, de se aliar aos grupos privilegiados, confiando neles a propensão para "compartilhar seus

\footnotetext{
${ }^{24} \mathrm{O}$ autor prefere utilizar o conceito de conservadorismo, por inspiração de Samuel Huntington, no sentido de uma "ideologia posicional", definida em contraposição às "investidas radicais" (Kaysel, 2015).

${ }^{25}$ MYRDAL, Gunnar. The challenge of world poverty. London: Allen Lane, 1970.
} 
interesses na "lei e ordem'” (Cruz, 2015, 17). Várias turbulências no século XX envolvendo a influência dos Estados Unidos na região tiveram desdobramentos na polarização direita e esquerda no continente, tendo-se delineado toda uma "nova agenda do conflito político" na América Latina a permitir a constatação de certos elementos de similaridade entre as pautas dos setores da direita política. Nessa lógica, estaria a se repetir um padrão de:

apoio eventual e políticas de modernização destinadas a 'civilizar' as relações econômicas e sociais na região, e alinhamento sistemático com as forças conservadoras quando, movido pelas reações despertadas pelo movimento visto 'prima facie' com simpatia, sai do controle ou toma rumos mais radicais (Cruz, 2015. p.37).

Coerente com essa perspectiva caminha a contribuição trazida por Rocha (2015), que foca na influência de certos "think tanks" "ativistas" na formação de redes de influência liberal no continente a partir dos Estados Unidos. Destaca especialmente uma construção institucional criada por Antony Fisher no início da década de 1980: a "Atlas Network". Inicialmente chamada de Atlas Economic Research Foundation, gradativamente constituiu-se como uma rede muito ampla em todo o planeta, chegando a 400 membros em mais de 80 países. Se o primeiro momento de existência da rede no continente foi marcado por uma conjuntura de predomínio de governos com tendências liberalizantes na América Latina, a partir dos anos 2000, com a configuração do fenômeno conhecido como "virada à esquerda", quando vários grupos políticos de tendência à esquerda no espectro político ideológico foram eleitos, esforços e recursos passaram a ser empreendidos no sentido do enfrentamento dessa nova realidade. Constatou-se uma significativa ampliação do número de organizações atuantes na região e

fenômenos simultâneos que provocaram um adensamento de organizações e redes nacionais e regionais. Vários 'think tanks' fundados ainda nos anos 1980 receberam uma injeção renovada de recursos humanos e materiais ou alcançaram um grau maior de influência e visibilidade. (...) Com isso, a visibilidade das pautas políticas e econômicas defendidas pelo movimento neoliberal aumentou consideravelmente (Rocha, 2015. p. 274). 
Significa, como a autora conclui, que a batalha político-ideológica tem sido travada cada vez mais no campo das ideias, na "valorização da disputa de hegemonia a partir da sociedade civil dentro de marcos democráticos".

Vale citar ainda o estudo de Boisard (2002) sobre a América Latina, o qual aponta para uma pluralidade de direitas com novas características e pautas principais em disputa no continente, cada qual identificada com marcadores determinantes, com relações plurais que atravessam as fronteiras nacionais e um trânsito significativo de ideias em relação aos Estados Unidos da América e à Europa. A autora revisa esforços conceituais da literatura de teoria política para essas abordar as direitas, revelando dificuldades para encontrar denominadores comuns.

Entender os fenômenos sociais concernentes a essas temáticas segue sendo um desafio que mobiliza muitos estudiosos das ciências sociais e o presente trabalho se insere nessa agenda maior de pesquisa. Expostas algumas contribuições teóricas, avançamos agora para apontamentos metodológicos.

\section{Aspectos metodológicos da pesquisa empírica}

Nesse momento apresentamos os critérios de escolha dos atores coletivos de cujas manifestações serão observadas na pesquisa empírica, as categorias utilizadas na análise e algumas limitações e desafios enfrentados durante a investigação.

Primeiramente, importa ressaltar que a pesquisa empírica restringiu-se a um trabalho de garimpo e prospecção nas páginas da rede social virtual "Facebook", no período de 01 de janeiro de 2017 a 01 de março de 2017. Não foram realizadas entrevistas e a nem tampouco se produziu alguma fonte primária.

A escolha dos atores coletivos alvos da pesquisa obedeceu primeiramente ao critério da autoidentificação dos atores, tanto com o Liberalismo ou com valores liberais, quanto com a direita política. Essa autoidentificação pode aparecer também de modo negativo, quando se assumem como frontalmente contra a hegemonia da esquerda ou contra qualquer forma de intervenção do Estado nas liberdades individuais e na livre iniciativa privada. Em parte dos casos, o ator traz a expressão "liberdade" ou "liberal" cunhada no próprio nome da organização. Em quase todos os casos 
referências de alguma das vertentes da teoria liberal aparecem na apresentação dos perfis dos atores. Também são vários os casos em que os grupos se definem de direita no espectro político ideológico. Em muitos casos os atores defendem explicitamente na sua apresentação oficial valores caros a certas vertentes do Liberalismo, como a defesa das liberdades individuais, do livre-mercado e da primazia da propriedade privada.

Uma série dos atores foi escolhida considerando a sua adesão à mencionada Atlas Network, cuja fundação e desenvolvimento, conforme vimos, nunca escondeu a simpatia pela teoria liberal, ao menos por algumas de suas vertentes ${ }^{26}$.

Também se considerou um elemento conjuntural brasileiro referente à militância dos atores na campanha pró-impeachment da Presidente Dilma Rousseff, contra o Partido dos Trabalhadores e contra a figura de Luis Inácio Lula da Silva, sobretudo levando em conta o teor dos discursos proferidos e os ataques acusando seus algozes de serem supostamente "socialistas", "comunistas", "esquerdistas" ou "bolivarianos", expressões nativas manipuladas de forma evidentemente pejorativa nas narrativas de seus autores ${ }^{27}$.

Mais especificamente a pesquisa empírica investiga as publicações de organizações e movimentos da sociedade civil pertencentes a três grupos:

- "think tanks" vinculados à Atlas Network 28: o Centro Interdisciplinar de Ética e Economia Personalista, o Estudantes pela Liberdade, o Instituto de Formação de Líderes, o Instituto Liberal, o Instituto Liberdade, o Instituto Millenium, o Instituto Ludwig Von Mises, o Instituto de Estudos Empresariais e o Instituto Líderes do Amanhã;

- os dois movimentos autodefinidos como liberais que ganharam protagonismo nas manifestações recentes anti-PT: o Movimento Brasil Livre e o Vem pra Rua;

\footnotetext{
${ }^{26}$ No caso da Atlas Network há claramente uma predileção de seus membros por vertentes do chamado "Liberalismo Clássico", cujas abordagens contemporâneas remetem a autores como Friedrich Hayek, Milton Friedman e Ludwig Von Mises(Gaus, s. d.) e da corrente "Libertariana", cuja referência maior é Robert Nozick, em relação à tradição do Liberalismo Igualitário, cujos autores contemporâneos de destaque são John Rawls, Thomas Nagel e Ronald Dworkin (Feres Junior., Campos, 2013).

${ }^{27}$ É certo que os governos do Partido dos Trabalhadores e seus principais expoentes políticos sofreram numerosas críticas por atores da esquerda no espectro político-ideológico, de modo que se faz necessário atentar para outros elementos do conteúdo das narrativas publicadas.

${ }^{28}$ Rocha (2015) explica toda a trajetória de formação da Atlas Network, destacando a importância do universo institucional desses e de outros "think tanks" na construção e na consagração da hegemonia das ideias liberalizantes nas últimas décadas ao redor do mundo.
} 
- e os atores da sociedade civil selecionados a partir de buscas pelas palavraschave "liberdade" e "liberal" e cujas tendências de conteúdo as situam à direita no espectro político-ideológico: a Frente de Ação Liberal, a Academia Liberalismo Econômico, a Frente pela Liberdade, o Liberdade Econômica e a Academia Liberdade.

Visa-se enquadrar as postagens sobre os eventos no sistema prisional ocorridos em janeiro de 2017 em perfis distintos, classificados entre o apreço liberal pela contenção do soberano e uma propensão autoritária, conforme a simpatia ou rejeição dos direitos civis das pessoas presas, passando por posições ambíguas. Também se registram as organizações que optaram pelo silêncio ou omissão.

Para ficar mais claro, pela categoria "apreço pela contenção do soberano" vamos considerar os discursos que manifestarem algum apreço por direitos civis de pessoas acusadas ou condenadas pelo Estado. Assim, por exemplo, estarão aquelas posições que criticarem as mortes ocorridas no interior das prisões, pelo fato de o Estado ter descumprido o seu dever de proteger as pessoas e de punir dentro dos limites legais. As manifestações consideradas como de "tendência autoritária", no outro extremo, são aquelas que, de alguma forma, considerem razoáveis ou "justos" os crimes cometidos nas unidades prisionais e não defendem o dever do Estado de proteção da vida de investigados e condenados pela prática de infrações penais.

Convêm ressaltar algumas das limitações e dificuldades encontradas na pesquisa. Primeiramente, a separação entre casos de direitos civis e de outras categorias de direitos pode parecer por vezes problemática na prática, abrindo espaço para eventual contestação. Os casos que podem incorrer em confusões serão pontualmente expostos, com as devidas ponderações da opção do pesquisador por esta ou por aquela classificação.

Houve dificuldades específicas com relação a alguns atores. No caso do Instituto Mises Brasil, por exemplo, encontramos ao menos duas páginas homônimas que podem confundir o pesquisador ou alguém interessado em seguir suas postagens. Trata-se de um problema recorrente em muitas pesquisas na rede mundial de computadores. Para evitá-lo ou mitigá-lo, neste e nos outros casos, verificou-se a identificação das páginas como "organização da sociedade civil” e definições como "perfil oficial" e até mesmo referências na página oficial das entidades fora da rede 
social. No caso do "Estudantes pela Liberdade", na Atlas Network o registro que consta alude ao sediado em Belo Horizonte. No Facebook não se localizou uma página específica de Belo Horizonte, mas apenas páginas de Uberlândia, Blumenau, Sergipe, Sul da Bahia e Petrópolis, e praticamente todas elas estiveram inativas durante o início de 2017. No caso do Instituto Liberal, na lista da Atlas Network aparece o Instituto Liberal de São Paulo e o do Rio de Janeiro. Como a página deste último é muito nova e posterior aos fatos registrados nas prisões, decidiu-se, para efeito da pesquisa, pela observação apenas das páginas nacional e paulista. Já a página do 'Instituto de Estudos Empresariais', do Rio Grande do Sul, não foi objeto de avaliação uma vez que seu acesso é fechado ao público e este pesquisador esteve com sua solicitação de ingresso pendente até a conclusão deste artigo.

Embora existam muitas páginas de tendências liberais no "Facebook", a opção de recorte de outros atores da pesquisa - para além dos 'think tanks' e das duas organizações protagonistas nas manifestações recentes - restringiu-se a grupos nacionais identificados expressamente como "organizações políticas", "ONGs" e "organizações da sociedade civil sem fins lucrativos". Isso excluiu organizações estrangeiras, páginas de humor (como Liberal da Zoeira), as páginas de músico/banda e as de organizações da iniciativa privada (como redes de mídia e de televisão). Outro critério adotado refere-se à exigência dessas páginas estarem ativas no período estudado, o que afasta aquelas páginas sem nenhuma postagem entre 01 de janeiro de 2017 a 01 de março de 2017.

Para além da análise meramente numérica e quantitativa da incidência de manifestações, há que se considerar a dimensão qualitativa, percebendo diferenças no tocante ao grau de institucionalidade, aos recursos e ao poder de formação de opinião dos atores coletivos estudados. Entre os mais poderosos nesses três aspectos figuram os "think tanks" 29 ligados à rede Atlas. O Movimento Brasil Livre, dotado de significativa

\footnotetext{
29 Não foram encontrados dados exatos sobre o orçamento e as formas de financiamento das organizações estudadas. Há muitas informações dispersas e uma pluralidade de fontes de recursos. Sabese, por exemplo, que o Movimento Brasil Livre angariou recursos de instituições partidárias - PMDB, DEM, Solidariedade e DEM - para a organização de protestos em 2014 e 2015 (Uol, 2016). A Atlas Network tem investido algumas dezenas de milhares de dólares anualmente em atores coletivos da sociedade civil na América Latina. Grandes empresas brasileiras como o grupo Gerdau e o grupo de mídia RBS também têm doado montantes significativos para essas organizações (Baggio, 2016).
} 
capacidade de influência, mas talvez ainda sem um grau de institucionalidade das primeiras organizações, também merece destaque. Em um grau menor de alcance e influência, com menos recursos e provavelmente com grau de institucionalidade inferior, parecem figurar os demais atores, compostos por espécies de movimentos sociais e organizações em processo de formação, o que se pode supor a partir das poucas informações disponíveis sobre elas nos respectivos perfis.

Feitos alguns apontamentos metodológicos, na próxima seção apresentaremos os resultados encontrados na observação das manifestações dos atores coletivos sobre os episódios de janeiro de 2017 em unidades prisionais de vários os estados da federação.

\section{Manifestações dos atores coletivos}

Os resultados da pesquisa empírica indicam o predomínio do silêncio e omissão sobre a temática. Dez dos quinze atores que puderam ser avaliados assim se posicionaram (ver Quadro 01). Essa postura representa certamente alguns significados, mas sua compreensão demandaria certos desdobramentos adicionais da pesquisa. Para não fugir do foco de atenção do presente estudo, vamos nos limitar a levantar algumas hipóteses sobre tais casos e dedicar maior atenção aos atores que se manifestaram explicitamente sobre os episódios nas prisões em janeiro de 2017. Alguns dos casos de omissões referem-se a perfis de organizações com rara ou nenhuma atividade no período estudado. São casos em que não se pode concluir nada.

Alguns casos denotam uma preocupação quase que exclusiva com temáticas da ordem econômica e do liberalismo econômico, como a do "Centro Interdisciplinar de Ética e Economia Personalista" ${ }^{30}$, a do "Instituto Liberdade"31, a da "Academia Liberalismo Econômico"32, a do "Liberdade Econômica"33 e a do "Academia

30 Página no Facebook do Centro Interdisciplinar de Ética e Economia Personalista. Disponível em: https://web.facebook.com/economiapersonalista/. Acesso em: 01 mar.2017.

31 Página no Facebook do Instituto Liberdade. Disponível em: https://www.facebook.com/institutoliberdade/?fref=ts. Acesso em: 01 mar.2017.

32 Página no Facebook da Academia Liberalismo Econômico. Disponível em: https://web.facebook.com/pg/ALEconomico/about/?ref=page internal. Acesso em: 01 mar.2017.

33 Página no Facebook da Liberdade Econômica. Disponível em: https://web.facebook.com/LiberdadeEconomica/?ref=br rs. Acesso em: 01 mar.2017. 
Liberdade" ${ }^{34}$. As páginas do "Instituto de Formação de Líderes" ${ }^{35}$ e do "Líderes do Amanhã" ${ }^{36}$ são mais caracterizadas pela divulgação de notícias e informações sobre o universo empresarial, abrangendo os mais variados setores da economia, incluindo uma quantidade significativa de vídeos sobre eventos. No caso do movimento "Vem pra rua" 37 , as pautas nesse período enfatizaram a "luta contra a corrupção" e a "renovação política", valendo destacar a ampla divulgação de protesto previsto para 26 de março de 2017 contra a corrupção. O mais próximo que se encontrou da temática do direito penal foi uma crítica contra o instituto legal brasileiro da prisão especial para pessoas com diploma de bacharel e uma contra o entendimento jurisprudencial segundo o qual a prisão só poderia ocorrer depois da condenação em segunda instância. São questões muito específicas que não se relacionam diretamente à problemática dos direitos civis. Vale mencionar que o tom adotado nas postagens é mais moderado do que o do outro protagonista liberal dos protestos recentes contra o governo de Dilma, o "Movimento Brasil Livre".

\begin{tabular}{|l|l|c|c|c|c|c|c|}
\hline \multicolumn{2}{|l|}{ Quadro 01. Posição dos atores em relação aos direitos humanos de pessoas presas } \\
\hline & $\begin{array}{c}\text { Apreço liberal } \\
\text { pela } \\
\text { contenção do } \\
\text { soberano }\end{array}$ & \multicolumn{2}{|c|}{ Ambíguos } & $\Leftrightarrow$ & $\rightarrow$ & $\begin{array}{c}\text { Propensão } \\
\text { autoritária }\end{array}$ & $\begin{array}{c}\text { Omissão } \\
/ \\
\text { Silêncio }\end{array}$ \\
\hline $\begin{array}{l}\text { Centro Interdisciplinar de Ética } \\
\text { e Economia Personalista/RJ }\end{array}$ & - & - & - & - & - & X \\
\hline $\begin{array}{l}\text { Estudantes pela Liberdade } \\
\text { Instituto de Estudos } \\
\text { Empresariais/RS }\end{array}$ & - & - & - & - & - & - \\
\hline Instituto de Formação de & & & & & & & $\mathbf{X}$ \\
\hline
\end{tabular}

34 Página do Facebook da Academia Liberdade. Disponível em: https://www.facebook.com/ACAD.LIBERDADE/?ref=br rs. Acesso em: 01 mar.2017.

35 Página no Facebook do Instituto de Formação de Líderes. Disponível em: https://web.facebook.com/institutodeformacaodelideres/?fref=ts. Acesso em: 01 mar.2017.

36 Página no Facebook do Líderes do Amanhã. Disponível em: https://www.facebook.com/MisesBrasil/?hc ref=SEARCH\&fref=nf. Acesso em: 01 mar.2017.

37 Página no Facebook do Vem Pra Rua. Disponível em: https://web.facebook.com/VemPraRuaBrasil.org/?fref=ts. Acesso em: 01 mar.2017. 


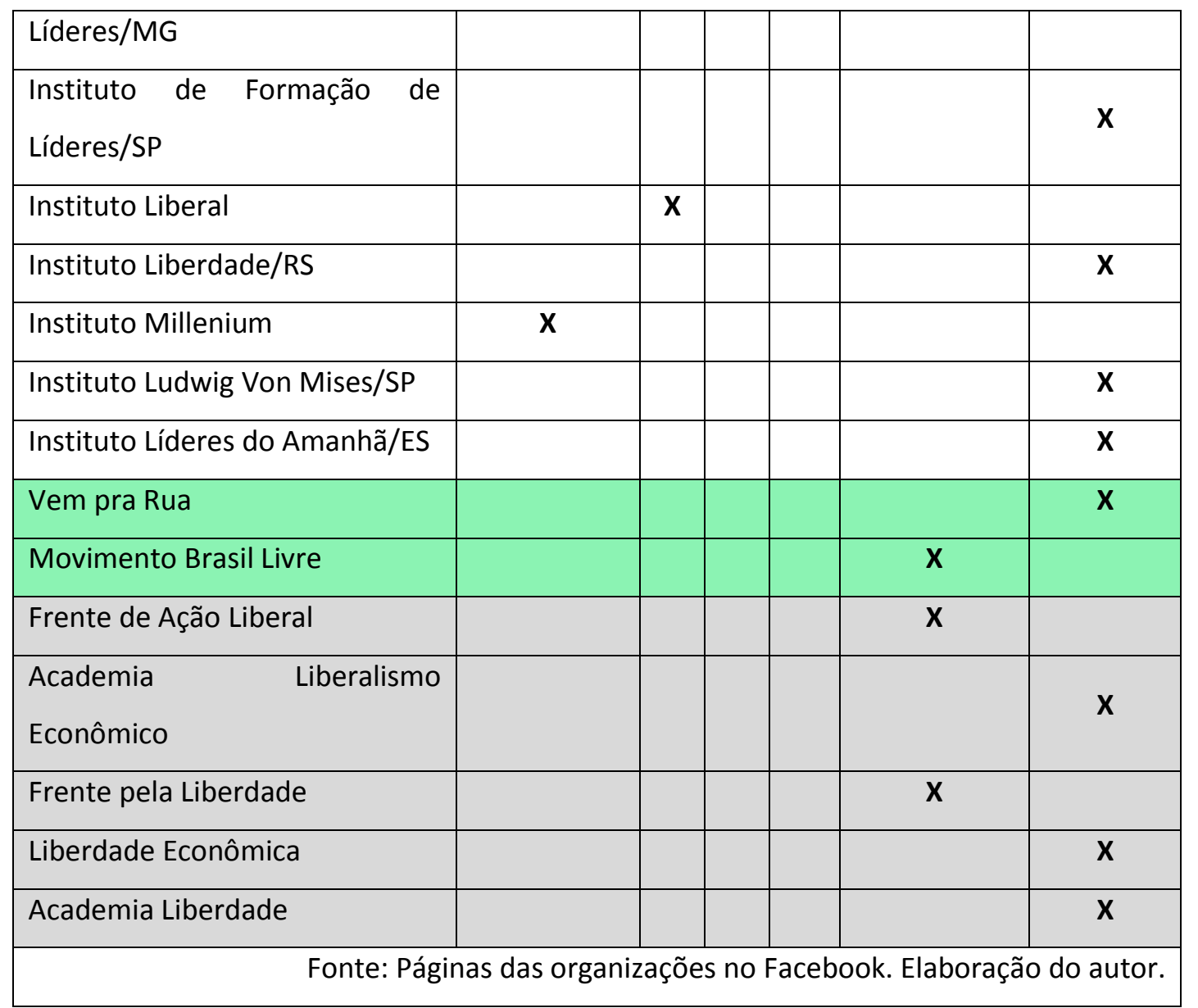

Entre as cinco organizações que postaram manifestações, mais da metade situase no polo da propensão autoritária (ver quadro 01).

Primeiramente, vale destacar um episódio da "crise prisional" de janeiro de 2017 que apareceu reiteradamente nas páginas observadas: uma das unidades mais problemáticas de Manaus era administrada por uma empresa em regime de concessão. Questionou-se nos órgãos de imprensa quanto à suposta responsabilidade da empresa pelos fatos e com relação à capacidade e limitações da iniciativa privada no provimento de serviços dessa natureza. Mais precisamente, constatou-se que o Instituto Liberal e a Frente pela Liberdade defenderam supostas vantagens da participação da iniciativa privada nesse setor, advogando por políticas de privatização de unidades prisionais. Ainda que não se trate de uma discussão que verse sobre os direitos civis e que a posição dos atores aqui não interfira na classificação proposta, o fato merece menção por revelar uma postura liberal dos atores no sentido econômico. Exceção foi a posição manifestada pelo entrevistado do Instituto Millenium Walter F. Maierovitch, para quem 
a privatização da função de "recuperar" ou "ressocializar" é inconstitucional e problemática $^{38}$.

Conforme exposto no Quadro 01, procuramos formular categorias capazes de contemplar possibilidades intermediárias entre os polos propostos, prevendo um enquadramento dos casos de concomitância de postagens em orientação dúbia ou ambígua, tendendo ora para um lado e ora para outro.

Nesse sentido, o Instituto Liberal ${ }^{39}$ parece um exemplo ao apresentar ambas as orientações políticas, com a prevalência numérica de uma sobre a outra. Por um lado, em 27 de fevereiro de 2017 criticou-se uma decisão do Supremo Tribunal Federal no sentido de indenizar presos submetidos a condições degradantes. Ora, considerando-se construções históricas como os princípios da vedação a penas cruéis e degradantes e a presunção de inocência, o direito a indenização nada mais é do que um direito da pessoa contra abusos cometidos pelo Estado. Por outro lado, publicou-se um artigo de autoria de Adolfo Sachsida, em 13 de janeiro de 2017, e outro de Sérgio Renato de Mello, em 06 de janeiro de 2017, ambos defendendo a indenização de pessoas mortas em unidades prisionais sob a tutela do Estado, com base em uma linguagem de direitos. Pelo conflito manifesto, decidiu-se pela classificação do instituto de modo ambíguo. Porém, não apenas pela vantagem numérica [2x1], como pela consistência argumentativa dos dois textos, coube um enquadramento tendente ao apreço liberal pela contenção do soberano.

Vale observar que o Instituto Liberal também publicou postagem pedindo o fim do benefício previdenciário do "auxílio-reclusão". Considerando que tal instituto configura um direito econômico, isso não foi considerado para efeito da classificação. Do mesmo modo, não foi considerada para fins do enquadramento do instituto a defesa da privatização de prisões encampada em outro momento.

\footnotetext{
${ }^{38}$ Instituto Millenium, 2017.

39 Página do Facebook do Instituto Liberal de São Paulo. Disponível em: https://www.facebook.com/pages/Instituto-Liberal-De-S\%C3\%A3o-Paulo-Ilisp/483792315091455?fref=ts. Acesso em: 01 mar.2017. E Página do Instituto Liberal do Brasil. Disponível em: https://www.facebook.com/institutoliberal/?fref=ts. Acesso em 01 mar.2017.
} 
Outro "think tank" que aparece em nossa análise é o Instituto Mises Brasil ${ }^{40}$. Dono de um perfil de aparência mais acadêmica e com um nível mais formal e menos militante de postagens, comparativamente aos outros atores, não tratou especificamente dos episódios de janeiro de 2017. Vale mencionar, porém, que em 06 de janeiro de 2017 a página do instituto republicou um texto de autoria de Geanluca Lorenzon, originalmente postado em fevereiro do ano anterior, sobre a história dos direitos humanos, desde sua origem liberal, até o período da Guerra Fria. De modo sintético, o artigo valoriza os direitos civis e políticos, em detrimento dos sociais, econômicos e culturais. Argumenta-se que a utilização da expressão para designar tantos direitos provocou uma tamanha expansão do conceito a ponto de banalizá-lo, de modo a não significar mais nada. Como não há nenhuma referência aos episódios, não há como inferir daí o posicionamento da organização a seu respeito.

O Instituto Millenium ${ }^{41}$ apresentou cinco postagens sobre a temática prisional no período estudado. Em 17.01.2017 divulgou-se o áudio de uma entrevista realizada pelo instituto com o especialista em segurança pública Leandro Piquet sobre a situação da segurança no país e os episódios ocorridos nas penitenciárias. O instituto lamenta que os governos dos estados da federação tenham grande desigualdade nos investimentos em políticas de segurança e de administração penitenciária e afirma que nunca foi construído no Brasil um "discurso democrático sobre a segurança pública", havendo uma histórica negligência dos governos civis e problemas graves de gestão, tanto do Executivo quanto do Judiciário. Defende mais gastos com o sistema prisional, ainda que os custos sejam altos. Na mesma data, o instituto divulga a entrevista do exsecretário nacional Anti-Drogas Walter Fanganiello Maierovitch para o jornal O Estado de S. Paulo, em que tece muitas críticas à falta de inteligência do Estado para lidar com os grupos criminosos. Vê as penitenciárias como um "sistema falido" e preconiza a necessidade de o Estado "retomar o controle das prisões", assumindo efetivamente o seu dever de zelar pela ressocialização dos presos de modo a mitigar as altas taxas de reincidência. Outra postagem é um artigo do advogado Antônio Penteado Mendonça,

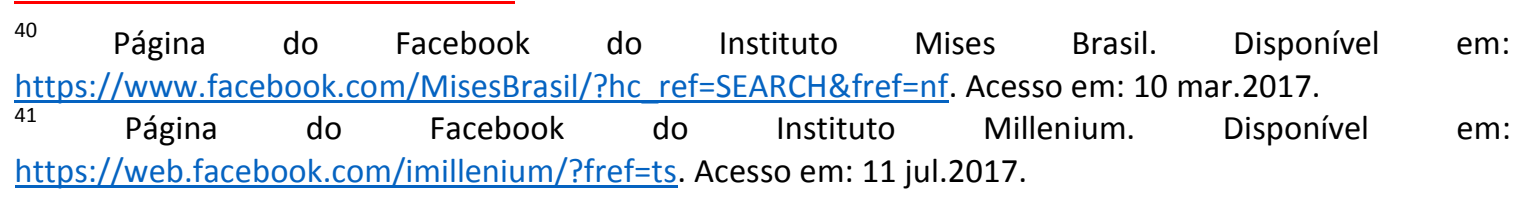


publicada no mesmo jornal, em 18 de janeiro de 2017, que acusa o Estado por ter falhado no tocante ao combate à violência e à criminalidade, algo que se inicia na omissão na prestação dos serviços sociais mais básicos em todo o país e vai se repetir no interior das unidades prisionais, formando uma espécie de vácuo que é ocupado pelas "facções criminosas". Em 02 de fevereiro de 2017 foi a vez de uma entrevista com o antropólogo Roberto DaMatta em que se critica certos privilégios injustificados do sistema punitivo brasileiro, com destaque para a prisão especial em casos de réu possuir diploma universitário. Em 23 de fevereiro de 2017 publicou notícia sobre o enorme número de presos provisórios no Brasil, invocando uma crítica ao uso excessivo dessa modalidade de privação de liberdade antes da formação da culpa. Pela linha geral coerente das postagens, que reclamam por uma presença mais efetiva do Estado no cumprimento de seus deveres, o instituto é classificado como "apreço liberal pela contenção do soberano".

O Movimento Brasil Livre (MBL) teve muitas postagens nesse período, com destaque para a divulgação de protesto previsto para 26 de março de 2017, os elogios aos primeiros meses da gestão do prefeito do município de São Paulo João Dória, a defesa da reforma da Previdência proposta pelo Governo Temer e do projeto do "Escola sem Partido" e os ataques ao Partido dos Trabalhadores e às suas lideranças. Com menor incidência quantitativa, o sistema prisional também foi objeto de atenção. Dois vídeos foram produzidos mostrando o líder do MBL Kim Kataguiri falando sobre os problemas de "segurança pública" e a "crise carcerária". No primeiro, de 11 de janeiro de 2017, preconiza que os presos arquem com seus custos e com indenizações às vítimas, defende a gestão compartilhada público-privada de unidade prisional, critica a indenização às famílias de presos mortos nas rebeliões e reproduz por duas vezes um discurso que contrapõe o bandido ao trabalhador. No segundo, de 17 de janeiro de 2017, defende as ações anunciadas pelo Ministro da Justiça Alexandre de Moraes de envio de tropas militares para ajudar a conter a "crise carcerária". Algo recorrente foi a divulgação de "memes" afirmando que "97\% dos brasileiros aprovam projeto de lei para que presos paguem suas despesas", sugerindo que o Estado abdicasse de seus gastos com o sistema prisional. O Deputado Federal do PSDB/PR Paulo Eduardo Martins aparece criticando os defensores de direitos humanos, acusando-os de serem petistas 
que advogam em interesse próprio, ao que o perfil do MBL anuncia como "Paulo Henrique Martins manda a real sobre a turma dos 'direitos humanos'”. Outro político que aparece é o Senador Magno Malta (PR/ES), Pastor Evangélico Presidente da Frente Parlamentar da Família, com declarações contra a decisão judicial de indenizar pessoas presas em condições degradantes. Em meados de janeiro, o MBL apoia a decisão do Governo Federal de enviar tropas das forças armadas. Outro post que merece ser citado mostra em um "meme" com uma fotografia da Deputada Maria do Rosário (PT/RS) acompanhada da frase: "Deputada defensora dos direitos humanos enfrenta dilema: não sabe se defende bandidos que mataram ou bandidos que morreram nos presídios". Enfim, em 02 de março de 2017 um "meme" é divulgado com a foto do Senador Ronaldo Caiado junto a uma frase cuja autoria atribuída a ele: "mandar indenizar presidiários é dar as costas para a sociedade". Por todo o exposto, resta clara uma posição tendente ao campo autoritário do MBL com relação aos direitos civis de pessoas presas.

A Frente de Ação Liberal ${ }^{42}$ autodefinia-se como "organização sem fins lucrativos". Informava sua data de criação como novembro de 2003 e contava com 160.360 curtidas em 02 de março de 2017. Nas palavras do próprio perfil, a organização visava

[...] reunir pessoas de ideais liberais republicanos e que repudiem qualquer pensamento socialista e antidemocrático. Buscamos um Brasil mais livre sustentados pelos quatro pilares fundamentais do liberalismo moderno: Liberdade, Livre Comércio, Direito a Propriedade e um Estado Mínimo.

De modo geral, nesse período estudado a página apresenta muitos ataques ao PT e aos dois ex-presidentes, embora também apareça um "meme" chamando todos os Presidentes civis da Nova República de "vagabundos". Registra-se também opiniões contra os direitos trabalhistas, os sindicatos, o estatuto do desarmamento, o "movimento feminista". Algumas postagens são mais informativas, reproduzindo notícias e artigos de periódicos.

Com relação aos eventos ocorridos em penitenciárias a postura da Frente de Ação Liberal é de propensão autoritária. É o que denota postagens como a que expõe 42 Perfil do Facebook da Frente de Ação Liberal. Disponível em: https://web.facebook.com/FrentedeAcaoLiberal/. Acesso em: 11 jul.2017. 
um quadro dividindo as temáticas que opõem direita e esquerda, prevendo os "direitos das vítimas" no primeiro polo e os "direitos dos bandidos" no último. Em outro momento, ao lembrar o caso em que o presidente do Conselho de Defesa da Pessoa Humana do estado de São Paulo foi acusado de ter envolvimento com o Primeiro Comando da Capital, afirma-se que "ONU e direitos humanos têm que ser destruídos", parecendo supor que todos os defensores de direitos humanos sejam criminosos. Em 07 de janeiro de 2017 comentam notícia sobre fuga de reclusos em penitenciária de Manaus afirmando que "direitos humanos só serve pra proteger bandido!".

A Frente pela Liberdade ${ }^{43}$ denomina-se "Organização não-governamental (ONG)", elege como público alvo a "juventude" e o "âmbito estudantil" e visa "propor mudança em nosso cenário político em todos os aspectos". No início de março de 2017 contava com 39.238 curtidas. No período estudado percebeu-se a simpatia pelas primeiras medidas da gestão do prefeito do município de São Paulo João Dória, constatou-se a publicação de algumas citações de pensadores do pensamento liberal econômico, com destaque para Milton Friedman, e de reiterados ataques ao Estado, aos impostos e ao controle de armas para a população civil. Algumas personalidades políticas da esquerda, como Guilherme Boulos e Jandira Feghali foram vítimas de ataques.

Com relação aos episódios nas penitenciárias, adotam uma postura que podemos enquadrar como de propensão autoritária. Basta ver que em 07 de janeiro de 2017 manifestam-se em solidariedade ao Secretário da Juventude do Governo Temer, demitido por ter sido flagrado torcendo pela ocorrência de outros episódios de massacres de presos. O título do post é "Secretário de Temer caiu por falar a verdade". Além disso, em 05 de janeiro de 2017 e em 13 de janeiro 2017 manifestam inconformismo em relação à indenização de familiares de presos mortos nas rebeliões. Em 05 de janeiro de 2017 repudiam as intervenções da Organização das Nações Unidas e da Anistia Internacional, quando cobraram das autoridades brasileiras uma "investigação isenta sobre a barbárie".

43 Perfil do Facebook da Frente Pela Liberdade. Disponível em:
https://web.facebook.com/frentepelaliberdade/?ref=br rs. Acesso em: 02 mar.2017. 
Fazendo um balanço desses resultados da pesquisa, considerando os dezoito atores selecionados, se não temos elementos para analisarmos as razões das omissões dos atores sobre o momento de aparente "caos" nas prisões de todo o país, constatamos resultados equilibrados em termos quantitativos, com dois atores de um lado e três do outro da tabela. Chamamos atenção para os resultados no ponto de vista qualitativo, o que pede para nos determos um pouco mais sobre estes atores e algumas de suas características. As entidades que manifestaram maior apreço pelo princípio liberal da contenção do soberano são justamente aquelas mais antigas, que construíram um ambiente institucional mais sólido ao longo do tempo: o instituto Liberal e o instituto Millenium. Ambas pertencem à Atlas Network e se dedicam ao estudo e difusão de certas crenças ligadas a tradições liberais. A primeira foi fundada em 1983, dedicado inicialmente para a tradução, edição e publicação de obras sobre liberalismo, passando depois a promover palestras, colóquios e seminários (Instituto Liberal, s. d.). O Instituto Millenium é mais novo, fundado entre 2005 e 2006, no primeiro mandato do governo Lula, influenciado pelo ambiente do Fórum da Liberdade e em um momento histórico de concepção de algumas organizações liberais que logo se conectariam em redes nacionais e internacionais (Rocha, 2015). Segundo sua própria página oficial na internet: "o think tank promove valores e princípios que garantem uma sociedade livre, como liberdade individual, direito de propriedade, economia de mercado, democracia representativa, Estado de Direito e limites institucionais à ação do governo" (Instituto Millenium, s. d.). De outro lado, as manifestações sobre os episódios de janeiro de 2017 que apontavam para uma propensão autoritária foram justamente de atores mais novos, sem uma institucionalidade tão consolidada. O MBL, entre eles, é certamente o mais estruturado e com capacidade de arrecadação de recursos, pela visibilidade alcançada nesses últimos anos. Foi criado como uma "marca" em 2013, na época das grandes manifestações de junho, para permitir a militância de integrantes da organização Estudantes pela Liberdade, superando determinados impedimentos legais, relacionados ao recebimento de recursos, e estatutários da Atlas Network, ligados à vedação de envolvimento com a política (Amaral, 2015). Ao longo do tempo o MBL se estruturou bastante, organizou congressos, definiu uma série de pautas, organizou vários atos e eventos, mas seguiu definindo-se como movimento. No 
Manifesto que figurava em sua página da internet em 2015 e que foi depois retirado do ar, figuravam cinco grandes pautas: "imprensa livre e independente", "liberdade econômica", "separação de poderes", "eleições livres e idôneas" e "fim dos subsídios diretos e indiretos a ditaduras" (Movimento Brasil Livre, 2015a). Ao invés desse manifesto, que era mais restrito a poucos princípios e uma curta apresentação, a página oficial do MBL passou a divulgar a partir de 2016 um leque amplo de propostas de políticas públicas que teriam sido aprovadas em um Congresso organizado no final de 2015 (Movimento Brasil Livre, 2015b).

Os outros dois cujas manifestações apontam para uma propensão autoritária, a Frente pela Liberdade e a Frente de Ação Liberal parecem atores bem menos organizados e talvez sejam mais adequadamente definidos como espécies de movimentos sociais ou como estruturas em processo de organização.

A Frente pela Liberdade nasceu durante o processo de impeachment de Dilma Roussef, em 2016, com base em Alagoas, por um grupo de jovens estudantes "cansados da hegemonia de pensamento e partidarismos das entidades estudantis já existentes". Apesar do nome e do fato de admitirem certa ecleticidade na sua composição, incluindo "liberais, libertários e conservadores" (Frente pela Liberdade, s.d.), predominam pautas mais ligadas ao credo liberal e libertário, como:

[...] a descentralização de poder, a redução de impostos, a maior autonomia para o indivíduo em face das instituições, o homeschooling, a luta contra a revolução cultural (gramiscismo e marxismo), a defesa da implantação do sistema de vouchers na educação, igualdade perante a lei, proteção da propriedade privada e do livre comércio, fim do estatuto do desarmamento, luta pela liberdade de pensar e etc (Frente pela Liberdade, s.d.).

A Frente de Ação Liberal (FAL) revela-se ainda muito menos institucionalizada e institucionalmente consolidada, a ponto de ter mudado de nome recentemente. Pois eis que quando da conclusão da última versão desse texto misteriosamente a página do Facebook do grupo havia sido retirada do ar. Isso intrigou esse pesquisador e o levou a investigar o que havia acontecido. Sabia que a FAL tinha alguma centralidade na figura de seu administrador, o empresário Alcides Ribeiro, pré-candidato a Deputado Estadual 
por Minas Gerais pelo Partido Novo em $2018^{44}$, porém na apresentação de seu perfil no Facebook ele estranhamente omitia essa vinculação institucional com a $\mathrm{FAL}$, ao passo que se apresentava como tendo participado da formação do MBL e como sendo um dos fundadores da Associação Brasileira de Fiscais da Conduta Política - a FISCOP -, esta "com 250 mil seguidores nas mídias sociais" ${ }^{45}$. O mistério termina tão logo clicamos com um cursor em algum dos links antigos ainda ativos da FAL encontrados em algumas das postagens antigas, o que nos conduz para a página da FISCOP. Conclusão: por algum motivo, uma virou a outra. Se em março de 2017, a data de criação remetia ao ano de 2003, a data postada em julho de 2018 era 2015, o que parece mais factível com o histórico de postagens e o que torna essa entidade contemporânea do MBL e da Frente pela Liberdade. Se naquele momento a página tinha 160.360 curtidas, em dezesseis meses o perfil repaginado angariou quase cem mil novas curtidas. Da antiga defesa aos princípios da "liberdade", "estado mínimo", "direito à propriedade" e "livre comércio", mudou para "compartilhamos de ideologia liberal, no que tange a economia, e conservadora, no que tange a costumes" ${ }^{46}$.

Assim, outra característica que podemos apontar como comum a esses três atores que revelaram propensão autoritária na pesquisa é a de serem mais voltados para a ação e militância política direta, enquanto os dois outros anteriores da Atlas Network são mais dedicados às atividades formativas e à difusão das crenças liberais.

\section{Considerações finais}

O principal resultado a destacar da pesquisa reside no fato de que, entre os atores que se manifestaram, aqueles mais antigos, com institucionalidade mais forte e

\footnotetext{
${ }^{44}$ Alcides Ribeiro gravara em 2016 ao menos dois vídeos no portal Youtube a favor da deposição de Dilma Rousseff onde declarava integrante da FAL, nos quais discursava junto ao logotipo do grupo, o desenho de uma pomba. São eles: i. "Frente Ação Liberal convoca greve", de 26 mar.2016 (Disponível em: https://www.youtube.com/watch?v= $8 \mathrm{dk} 59 \mathrm{cdw}$. Acesso em 31 jul.2018) e ii. "O que falta a Dilma é caráter", de 27 abr. 2016 (Disponível em: https://www.youtube.com/watch?v=EnjvDnwMTDs. Acesso em: 31 jul. 2018).

45 Perfil de Alcides Ribeiro S. Júnior no Facebook. Disponível em: https://www.facebook.com/pages/story/reader/?page story id=201728437255680. Acesso em $31 \mathrm{jul}$. 2018.

${ }_{46}$ Esse trecho comparou a antiga página da Frente de Ação Liberal (Disponível em: https://web.facebook.com/FrentedeAcaoLiberal/. Acesso em: 11 jul.2017) com a página atual da FISCOP, ambas no Facebook (Disponível em: https://www.facebook.com/pg/fiscop/about/?ref=page internal. Acesso em: 31 jul.2018).
} 
com âmbito de atuação mais voltado para a formação de pessoas e difusão de valores liberais mostraram mais apreço pelo princípio de restrição de poder do soberano do que os atores mais novos, menos institucionalizados e mais voltados para a ação política direta.

A retomada de conceitos e discussões teóricas dessa natureza para a leitura do campo de ação de atores políticos pode ter benefícios cognitivos de ordem intelectual, de modo a compreender linhas de pensamento difundidas no cotidiano em um momento histórico turbulento de polarização no campo político-ideológico. Há ainda vantagens de ordem pragmática, no sentido de possibilitar a consciência sobre os interlocutores e possíveis opositores nos dois lados das disputas em torno de direitos humanos no sistema punitivo.

Constatam-se nos resultados desta pesquisa, coerente com Boisard (2014), as grandes heterogeneidades entre as organizações da direita política brasileira. Mais especificamente vê-se a pluralidade de posições adotadas apenas em agrupamentos identificados com valores liberais. Na rede mundial de computadores atuam os mais variados grupos, dos mais tradicionais aos mais contemporâneos, com integrantes com melhor e maior formação intelectual e científica, aqueles com maior identificação com os valores do liberalismo econômico, aqueles com maior afinidade com o liberalismo político e mesmo aqueles que reproduzem alguma confusão quanto à própria identidade. Conforme Gaus, Courland e Schmidtz (2015) ensinam, não há nisso propriamente uma incoerência teórica, uma vez que o Liberalismo abrange uma pluralidade de significados.

A proximidade de posições tomadas nesse debate pelas duas entidades consideradas como "think tanks" liberais vinculados à Atlas Network pode se explicar talvez pelo próprio vínculo institucional estabelecido, o que denotaria algum êxito no projeto de rede. Mas considerando que os recentes esforços dos "think tanks" enfatizaram muito mais a agenda do liberalismo econômico, o silêncio de parte dos atores frente aos episódios talvez possa ser explicado nessa linha.

De outro lado, outros atores parecem se comportar com maior informalidade e em uma militância política mais explícita, com o uso frequente de recursos comunicativos de apelo mais emotivo e irônico. 
Por certo, contradições entre o comportamento político prático e a respectiva tradição ideológica acontecem da esquerda à direita. Atores políticos coletivos são compostos por uma pluralidade de atores individuais, com disparidades internas e distintos graus de coesão e coerência com determinadas tradições teóricas.

A convergência entre as organizações que se manifestaram na posição autoritária em relação aos direitos civis das pessoas presas pode significar talvez alguma confusão ou ignorância em relação à ideia de contenção do soberano do liberalismo político, senão uma postura autoritária consciente nessa temática.

As manifestações e mesmo o silêncio podem revelar aspectos de interesse para a agenda de pesquisa sobre as ideologias políticas e sobre o perfil dos atores importantes que compõem o espectro político da direita no país.

Apesar de discursos em disputa em boa parte da Guerra Fria, que atingiram o ápice na construção dos Pactos Internacionais de 1966, a ideia da indivisibilidade e interdependência dos direitos humanos, consagrada finalmente na Convenção de Viena de 1993, e a própria historiografia mostram como as gramáticas de direitos humanos não cabem de modo cartesiano na dicotomia direita-esquerda ${ }^{47}$. Sobretudo no âmbito da sociedade civil organizada, formas de apropriação e reformulação de significados mudam conforme as conjunturas políticas, tornando as fronteiras por vezes esfumaçadas. É um território dinâmico de transformações a demandar periódicas atualizações do diagnóstico.

A dificuldade de definição da direita no país e no continente segue sendo um desafio complexo a demandar novas reflexões e estudos. A autoidentificação dos atores com a direita deve ser combinada com elementos relacionais da esfera pública e com a observação da adesão a valores, comportamentos e manifestações.

O que quer que entendamos como "novas direitas", não pode ser visto de modo completamente isolado de certas tradições e das construções sociais, culturais e institucionais, de âmbito nacional e internacional ${ }^{48}$. A gênese histórica dos grupos liberais a partir da independência brasileira fornece algumas pistas para uma análise de

\footnotetext{
${ }^{47}$ Sobre a história de tensões em torno dos direitos humanos no período da Guerra Fria e a reflexão em relação ao plano ideológico, indica-se a leitura de Lefort (2011) e Moyn (2010).

${ }^{48}$ A revisão de literatura de pesquisas sobre as direitas na América Latina promovida no trabalho de Boisard (2014) traz alguns exemplos de formulações teóricas sobre a emergência de "novas direitas".
} 
aspectos das manifestações verificadas na pesquisa, e mesmo sobre o silêncio ou omissão. Apesar de alguns lapsos temporais de afastamento, é significativo o fato de que os conservadores e os liberais estiveram muito próximos uns dos outros por longos períodos de nossa história.

Em vários aspectos, o período recente de ascensão de governos de esquerda no Brasil e em parte da América Latina incomodou os grupos identificados com a direita. Esse fenômeno da "virada à esquerda" uniu muitos desses grupos em uma espécie de plataforma discursiva e de ação comum contra um mesmo inimigo. Muitos investimentos foram realizados na elaboração de novas estratégias de ação, recrutamento e formação de quadros, em um âmbito onde se inserem com destaque os "think tanks" de tendências liberais. Nesse cenário a agenda política e a percepção dos atores sobre os direitos humanos não estão imunes a algum impacto.

\section{Referências bibliográficas}

AMADEO, Sérgio. 2015. As origens do liberalismo: liberdade e propriedade no pensamento político do século XVII. Perspectivas, v. 46, pp. 9-36, jul/dez. 2015. Disponível em: https://periodicos.fclar.unesp.br/perspectivas/article/view/10052/6607. Acesso em 28 jul.2018.

AMARAL, Marina. 2015. A nova roupa da direita. Pública, 23 jul. 2015. Disponível em: http://bit.ly/2kw7IWh. Acesso em 31 jul.2018.

A TRIBUNA. 2017. Manaus registra novas mortes de presos e rebeliões; veja histórico, 09 jan.2017. Disponível em: http://www.atribuna.com.br/noticias/noticiasdetalhe/atualidades/maranhao-teve-mais-uma-noite-com-morte-de-presos-e-rebeliao-vejahistorico/?cHash=c4c9b4b3b1dc4b722926846075ffce5e. Acesso em: 05 abr.2017.

BAGGIO, Kátia Gerab. 2016. Conexões ultraliberais nas Américas: o think tank norte-americano Atlas Network e suas vinculações com organizações latinoamericanas. Anais do XII Encontro Internacional da Associação Nacional de Pesquisadores e Professores de História das Américas. Campo Grande.

BARATTA, Alessandro. 2002. Criminologia crítica e crítica ao direito penal: introdução à sociologia do direito penal. Rio de Janeiro: Revan.

BECCARIA, Cesare. 1993. Dos delitos e das penas. São Paulo: Hemus - Livraria Editora Ltda.

CALDEIRA, Teresa Pires do Rio. 2000. Cidade de muros: crime, segregação e cidadania em São Paulo. São Paulo: Ed. 34, Edusp. 
CONSELHO REGIONAL DE PSICOLOGIA DO MATO GROSSO DO SUL. 2017. Falta de direitos humanos promovo crise penitenciária, afirmam especialistas. 29 mai.2017. Disponível em: http://www.crpms.org.br/noticia/falta-de-direitos-humanos-promove-crise-prisional-apontamespecialistas/749\#.WYoRy1GGPIU. Acesso em: 08 ago.2017.

CULT. 2018. Dossiê: "Quem são e o que pensam as 'novas' direitas brasileiras?". N. 34, ano 21, mai.2018.

CRUZ, Sebastião Velasco e. 2015. Elementos de reflexão sobre o tema da direita (e esquerda) a partir do Brasil no momento atual. In: CRUZ, Sebastião Velasco e. KAISEL, André. CODAS, Gustavo. Direita, volver! O retorno da direta e o ciclo político brasileiro. São Paulo: Editora Fundação Perseu Abramo.

CRUZ, Sebastião Velasco e. KAISEL, André. CODAS, Gustavo. 2015. Direita, volver! O retorno da direta e o ciclo político brasileiro. São Paulo: Editora Fundação Perseu Abramo.

DIAS, Camila Caldeira Nunes. 2013. PCC: hegeminia nas prisões e monopólio da violência. São Paulo: Saraiva.

EBC. 2017. Entenda a crise no sistema prisional brasileiro, 24 jan.2017. Disponível em: http://www.ebc.com.br/especiais/entenda-crise-no-sistema-prisional-brasileiro. Acesso em 30 jul.2018.

FERES JÚNIOR. João. CAMPOS, Augusto. 2013. Liberalismo igualitário e ação afirmativa: da teoria moral à prática pública. Revista de Sociologia e Política, v. 21, n. 48, pp. 85-89. Disponível em: http://www.scielo.br/pdf/rsocp/v21n48/a05v21n48.pdf. Acesso em 27 jul.2018.

FERREIRA, Aurélio Buarque de Holanda. 2004. Novo dicionário Aurélio da Língua Portuguesa. 3a Ed. Curitiba: Positivo.

FOLHA DE SÃO PAULO. 2017 (2017a). Cadeia está virada, diz diretor de Alcaçus; presos estão nos telhados, 16 jan.2017. Disponível em: http://www1.folha.uol.com.br/cotidiano/2017/01/1850201-cadeia-esta-virada-diz-vice-diretorde-alcacuz-presos-estao-nos-telhados.shtml. Acesso em: 05 abr.2017.

FOLHA DE SÃO PAULO. 2017 (2017b).Em quatro meses, fugas em massa em SP equivalem a uma prisão inteira, 24 jan.2017. Disponível em: http://m.folha.uol.com.br/cotidiano/2017/01/1852791-em-quatro-meses-fugas-em-massa-emsp-equivalem-a-uma-prisao-inteira.shtml. Acesso em: 05 abr.2017.

FOLHA DE SÃO PAULO. 2017 (2017c). Para especialistas, caos no sistema penitenciário é regra em todo o país. 03 jan.2017. Disponível em: http://www1.folha.uol.com.br/cotidiano/2017/01/1846549-para-especialistas-caos-nasprisoes-e-regra-em-todo-o-pais.shtml. Acesso em: 08 ago.2017.

FOLHA DE SÃo PAULO. 2017 (2017d). Veja quem são todos os 31 dos 33 mortos no massacre de Roraima, 07 jan.2017. Disponível em: http://www1.folha.uol.com.br/cotidiano/2017/01/1847899-veja-quem-sao-todos-os-31presos-mortos-no-massacre-de-roraima.shtml. Acesso em: 05 abr.2017.

FOLHA DE SÃO PAULO. 2017 (2017e). Veja um resumo da crise nos presídios que deixou 102 mortos neste ano, 10 jan. 2017.2 Disponível em: 
https://www1.folha.uol.com.br/cotidiano/2017/01/1848464-veja-um-resumo-da-crise-nospresidios-que-deixou-102-mortos-neste-ano.shtml . Acesso em 30 jul.2017.

FRENTE PELA LIBERDADE. s.d. História. Página oficial da organização. Disponível em: https://frentepelaliberdade.com.br/historia/. Acesso em 31.07.2018.

G1. 2017 (2017a).Após explosão de muro, presos fogem de penitenciária do Paraná, 15 jan.2017. Disponível em http://g1.globo.com/pr/parana/noticia/2017/01/apos-explosao-demuro-presos-fogem-de-penitenciaria-do-parana.html. Acesso em: 02 jul.2017.

G1. 2017. (2017b). Manaus registra 12 homicídios após rebelião e fugas de presos, 06 jan.2017. Disponível em http://g1.globo.com/am/amazonas/noticia/2017/01/manaus-registra-12homicidios-apos-rebeliao-e-fugas-de-presos.html. Acesso em: 02 jul.2017.

G1. 2017. (2017c). Relatório aponta que há 71 desaparecidos e número de mortos em Alcaçus pode se aproximar de 100, 16 mai.2017. Disponível em http://g1.globo.com/rn/rio-grande-donorte/noticia/relatorio-aponta-que-ha-71-presos-desaparecidos-e-numero-de-mortos-emalcacuz-pode-se-aproximar-de-100.ghtml. Acesso em: 02 jul.2017.

G1. 2017. (2017d).RN registra rebelião em mais uma unidade prisional, 18 jan.2017. Disponível em: http://g1.globo.com/rn/rio-grande-do-norte/noticia/2017/01/rn-registra-rebeliao-emmais-uma-unidade-prisional.html. Acesso em: 02 jul.2017.

GAUS, Gerald. COURLAND, Shane D. SCHMIDTZ, David. 2015. Liberalism. Stanford Encyclopedia of Philosophy. Disponível em: https://plato.stanford.edu/entries/liberalism/. Acesso em: 27 nov.2017.

GAUS, Gerald. s.d. Hayek, complexity anb "classical" liberalism. Arquivo não publicado. Disponível em: http://www.gaus.biz/HayekianLiberalism.pdf. Acesso em: 27 jul.2018.

HEYWOOD, Andrew. 2002. Politics. 2nd edition. New York: Palgrave Macmillan.

INSTITUTO LIBERAL. s.d. Quem somos. Página oficial da organização na internet. Disponível em: https://www.institutoliberal.org.br/quem-somos/. Acesso em: 31 jul.2018.

INSTITUTO MILLENIUM. 2017. 'Estado tem que atacar a base econômica das máfias', diz Walter Maierovitch, 17 jan.2017. Disponível em: http://www.institutomillenium.org.br/blog/estadotem-que-atacar-base-economica-das-mafias-diz-walter-maierovitch/. Acesso em: 11 jul.2017.

INSTITUTO MILLENIUM. s.d. Quem somos. Página oficial da organização na internet. Disponível em: https://www.institutomillenium.org.br/institucional/quem-somos/. Acesso em: 31 jul.2018.

KAYSEL, André. 2015. Regressando ao regresso: elementos para uma genealogia das direitas brasileiras. In: CRUZ, Sebastião Velasco e. KAISEL, André. CODAS, Gustavo. Direita, volver! 0 retorno da direta e o ciclo político brasileiro. São Paulo: Editora Fundação Perseu Abramo.

LEFORT, Claude. 2011. A invenção democrática: os limites da dominação totalitária. 3ạ ed., revista e atualizada. Trad. Isabel Loureiro, Maria Leonor Loureiro. Belo Horizonte: Autêntica editora (Invenções democráticas, v. 3).

MATTEUCCI, Nicola. 2000. Liberalismo. In: BOBBIO, Norberto. MATTEUCCI, Nicola. PASQUINO, Gianfranco. Dicionário de Política, 5a Ed., vol. 02. Brasília: Imprensa Oficial, pp. 686-705. 
MELLO, Leonel Ituassu Almeida. 2004. John Locke e o individualismo liberal. In: WEFFORT, Francisco C. (org.). Os clássicos da política, vol. 01, 13ạ ed. São Paulo: Ática.

MOVIMENTO BRASIL LIVRE. 2015 (2015a). Manifesto. Página oficial. Disponível em: https://web.archive.org/web/20151219172604/http://mbl.org.br:80/manifesto/. Acesso em 31 jul.2018.

MOVIMENTO BRASIL LIVRE. 2015 (2015b). Propostas aprovadas no primeiro congresso nacional do Movimento Brasil Livre em novembro de 2015. Página oficial.

MOYN, Samuel. 2010. The last utopia: human rights in history. Cambridge, Massachusetts, and London, England: The Belknap Press of Harvard University Press.

PAINE, Thomas. 2005. Direitos do homem. Bauru: Edipro.

ROCHA, Camila. 2015. Direitas em rede: think tanks da direita na América Latina. In: CRUZ, Sebastião Velasco e. KAISEL, André. CODAS, Gustavo. Direita, volver! O retorno da direta e o ciclo político brasileiro. São Paulo: Editora Fundação Perseu Abramo.

ROCHA, Camila. 2018. Quem são e o que querem. CULT, n. 34, ano 21, mai.2018.

SINGER, André. 2018. O Lulismo em crise: um quebra-cabeça do período Dilma (2011-2016). São Paulo: Companhia das Letras.

UOL. 2017 (2017a). Dez detentos fogem de presídio na região metropolitana de BH, 15 jan.2017. Disponível em: https://noticias.uol.com.br/cotidiano/ultimasnoticias/2017/01/15/dez-detentos-fogem-de-presidio-na-regiao-metropolitana-de-bh.htm. Acesso em: 02 jul.2017.

UOL. 2017. (2017b). Em 19 dias, 17 detentos morreram em unidades prisionais do Rio de Janeiro, 19 jan.2017. Disponível em: https://noticias.uol.com.br/ultimas-noticias/agenciabrasil/2017/01/19/em-19-dias-17-detentos-morreram-em-unidades-prisionais-do-rio-dejaneiro.htm. Acesso em: 02 jul.2017.

UOL. 2017. (2017c). Em menos de 24 horas, 38 detentos fogem de presídios na Bahia, 14 jan.2017. Disponível em: https://noticias.uol.com.br/ultimas-noticias/agenciaestado/2017/01/14/em-menos-de-24-horas-38-detentos-fogem-de-presidios-na-bahia.htm.

Acesso em: 02 jul.2017.

UOL. 2017. (2017d). Mais de 6 horas após rebelião em Bauru (SP), governo diz que 152 presos fugiram, 24 jan.2017. Disponível em: https://noticias.uol.com.br/cotidiano/ultimasnoticias/2017/01/24/mais-de-6h-apos-rebeliao-em-bauru-sp-governo-diz-que-152-presosfugiram.htm . Acesso em: 05 abr.2017.

UOL. 2017. Máquina de partidos foi utilizada em atos pró impeachment, diz líder do MBL, 27 mai.2016. Disponível em: https://noticias.uol.com.br/politica/ultimasnoticias/2016/05/27/maquina-de-partidos-foi-utilizada-em-atos-pro-impeachment-diz-lider-dombl.htm. Acesso em: 10 ago. 2017.

UOL. 2017. (2017e). Presos tentam fugir de penitenciária alvo de massacre em Roraima, 12 jan.2017. Disponível em: https://noticias.uol.com.br/cotidiano/ultimasnoticias/2017/01/12/presos-tentam-fugir-de-presidio-alvo-de-massacre-em-roraima.htm.

Acesso em: 02 jul.2017. 
UOL. 2017. (2017f). SP registra as primeiras mortes em presídios no ano, no Brasil são 103, 13 jan.2017 Disponível em: https://noticias.uol.com.br/cotidiano/ultimas-noticias/2017/01/13/spregistra-as-primeiras-mortes-em-presidios-no-ano-no-brasil-sao-103.htm. Acesso em: 02 jul.2017.

WALDRON, Jeremy. 2012. Os fundamentos teóricos do Liberalismo. Trad. Lucas Petroni. Leviathan: cadernos de pesquisa política, n. 05, pp. 102-132. Disponível em: http://dx.doi.org/10.11606/issn.2237-4485.lev.2012.132312. Acesso em: 25 jul.2018.

Tramitação do artigo na revista Submetido: 16/04/2018

Revisões requeridas: 10/07/2018

Versão revista: 01/08/2018

Aceito: 09/10/2018 